\title{
Monitoring land use/cover change using digital classification techniques: A case study of Sadhera Mines, Satna, Madhya Pradesh, India
}

\author{
A.Tiwari, S. Karwariya and S.Tripathi
}

\begin{abstract}
Land use land cover is an important part to understand present as well as past status of the earth's surface. Land use and land cover are two different terminologies. Land use and land cover is dynamic in nature and provides a comprehensive perceptive of human activities with the environment. As land is becoming a scarce resource due to immense agricultural and demographic pressure, therefore the information on land use land cover and possibilities for their optimal use is essential for the selection, planning and implementation of land use schemes to meet the increasing demands for basic human needs and welfare. The study area is in the limelight due to continuous mining leading to large scale reduction in dense forest. The main objective of this study is to monitor change in landuse and land cover in sadhera and its surrounding mines of Katni district by using of remote sensing and geographic information system technique. The land use land cover change detection has been performed based on the analysis of the digital data of landsat TM (30 Meter) and landsat 8 (OLI)+ Pan (15 Meter) pertaining to 2009-10 and 2015-16. It has been observed that there has been a significant change in the land use pattern with an increase of $287.46 \%$ in the mining area whereas the area under dense forest has decrease drastically by $-60.21 \%$. Hence, the information obtained from landuse landcover change detection map help to provide optimal solutions for the selection, planning, implementation and monitoring of mining areas.
\end{abstract}

Index Terms - Change detection, Land use / Land cover, Landsat data, Remote sensing.

\section{INTRODUCTION}

Mining relates to the extraction of stones, soils, minerals etc.from the earth. Material extracted from the earths inclu id precious stones like diamond, gems as well as petroleums.

Land use relates to the man maid or economical activity on specific piece of land (Lillesand et al. 2004). Human induced activity easily identify on ground for examples agricultural practices, urban development, grazing, logging, and mining. Whereas, land cover relates to the natural features on earth. It incluid natural features such as forest, river, hills etc. (Cihlar 2000). The term land cover initially referred to the type and state of vegetation, but it has broadened in following usage to include human Structures such as urban development, and other aspects of the natural environment, such as Soil type, biodiversity, and surface and groundwater (Meyer 1995). Land cover categories Generally include river, forests,

Manuscript published July 31, 2016. This work was a part of M.Sc. Project work submitted in Mahatma Gandhi Chitrakoot Gramodaya University, Satna Madhya Pradesh, India

Awantika Tiwari, Mahatma Gandhi Chitrakoot Gramodaya University, S Madhya Pradesh (India)-485001 (email:awantika.karwariya@gmail.com)

Sateesh Kumar Karwariya, Indian Institute of Soil Science, Bhopal Madhya Pradesh (India)- 462038 (e-mail: sateesh.karwariya@gmail.com)

Shashikant Tripathi, Mahatma Gandhi Chitrakoot Gramodaya University,Satna Madhya Pradesh (India) (e-mail: tripathi.shashikant@ gmail.com). wetlands, pastur, soil characteristics, climate, topography and vegetation. etc.

Land is a basic unit of production, and through much of the course of human history, it has been tightly coupled with economic growth. Often improper management of land is causing different forms of environmental degradation (Karwariya, et al. 2011). For sustainable exploitation of the land resource, it is essential to know the natural characteristics, extent and location, its quality, productivity, suitability and limitations of various land uses (Mishra et al. 2012). Land use is a product of interactions between a society's cultural background, state, and its physical needs on the one hand, and the natural potential of land on the other (Balak Ram and Kolarkar 1993). In order to improve the economic condition of the area without further deteriorating the bio environment, every bit of the available land has to be used in the most rational way.

Change detection is the technique by which we monitor and identify the changes occure during the given time period. For this purpose multi-date (temporal) satellite images of different resolutions are used to compare and find out the type and amount of change have occurred. Land use change observation and monitoring programs now rely on remotely sensed data coupled with field observations and corroborating information describing the social, economic, and physical dimensions of land use and land cover. Remote sensing approaches for observing and monitoring change, vary depending on the geographic scope, ecological complexity, and the information required understanding ecosystem interactions. Strategies based on identifying spectral variability are useful for targeting areas of rapid change.

Thus, this study is to find the impact of mining activity on landuse landcover area.

\section{STUdy AREA}

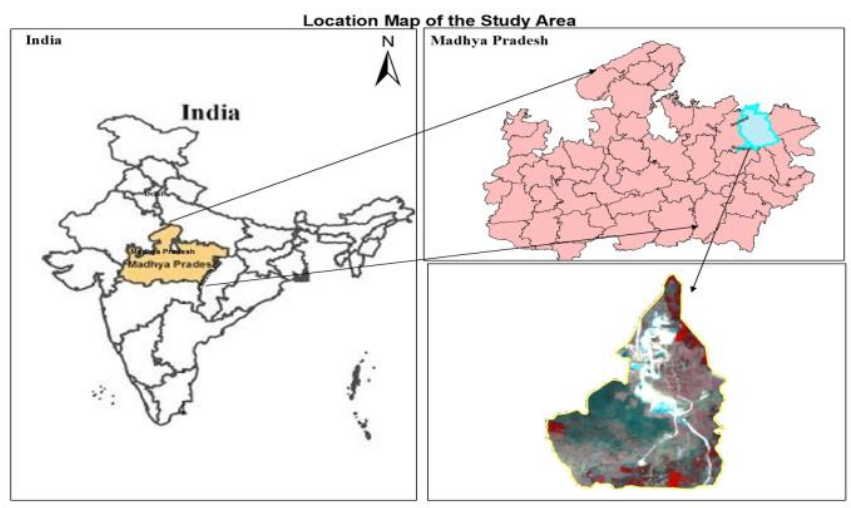

Fig.1. Location map of study area

The study area is located in revenue villages Sadhera of Maihar block Madhya Pradesh. The mining lease (ML) area 
is at a distance of $18 \mathrm{~km}$ south of Maihar town. It can be approached by road following national highway no. 7 connecting Katni-Rewa upto Varanasi. The nearest railway station is Bhadanpur, which is connected by Katni-SatnaRewa line of central railway where as nearest airport is Khajuraho.It extends between the latitude $2407^{\prime} 3.2^{\prime \prime} \mathrm{N}-240$ 08 ' 55.4" $\mathrm{N}$ and between 800 44' 24.9'"E - 800 46' 8.9" E longitudes. The total geographical area of core area is 389.1 hac. The western part have hills. The limestone mines found in the northern part of study area. The maximum length of the study area is about $3 \mathrm{~km}$. from north to south and width about $2 \mathrm{~km}$.

The typical monsoon climate of the area has three distinct seasons like summer (March-June), rainy (July-October) and winter (November-February). The months of may and June are generally the hottest, the maximum temperature exceeds to $440 \mathrm{C}$ during mid may, while the coolest months are December and January, the minimum temperature drops to 20C and monsoon arrives in mid june and continues till late september. The mean annual rainfall over the period from 2010 to 2015 has been $1104.78 \mathrm{~mm}, 82.8 \%$ of which occurred within four months of the monsoon season (June September).

\section{MATERIALS AND MEthods}

The landsat-TM and Landsat-8 (OLI) images acquired in February 2009 and 2015 was used mainly for the analysis and georeferenced (Universal Transverse Mercator-UTM, WGS84) to 1:50000 digital topographic maps by nearest neighbor resampling algorithm and the RMSe was less than one pixel in ERDAS Imagine version 9.3 (Leica Geosystems, Atlanta, U.S.A.) software. The data sets were imported in, the image processing software to create a false colour composite (FCC). The layer stack option in image interpreter tool box was used to generate FCCs for the study areas. The sub-setting of satellite images were performed for extracting study area from both images by taking geo-referenced out line boundary of mining area AOI (Area of Interest). Image fusion techniques done in Erdas Imagine Software, this technique is very useful to integrate the geometric detail of a high-resolution panchromatic (PAN) image Band-8 (15 Meter) and the spectral information of a low-resolution multispectral (MSS) image (30 Meter), particularly important for understanding land use dynamics at larger scale (1:25000 or lower), which is required by the decision makers to adopt holistic approaches for regional planning. Fused images can extract features from source images and provide more information than one scene of MSS image. High spectral resolution aids in identification of objects more distinctly while high spatial resolution allows locating the objects more clearly. The final classified maps were prepared in Arc map9.3 software.

The study is mainly based on primary sources of data, the data used for the preparation of land use/land cover map is multidate multispectral satellite data of landsat 8+ Pan (15 Meter) \& landsat TM (30 Meter) of the year 2015 and 2009 on 1:50,000 scale. Similarly, the secondary data were used for validation of land use/land cover maps. A variety of remote sensing change detection methodologies have been developed and evaluated over the past thirty years. For this study an integrated geospatial approach, i.e. remote sensing and GIS in conjunction with secondary data has been adopted. The remote sensing and GIS data were handled with the help of Erdas Imagine 9.3 and Arc GIS Desktop 9.3 respectively. The detailed methodology of the study is given below:

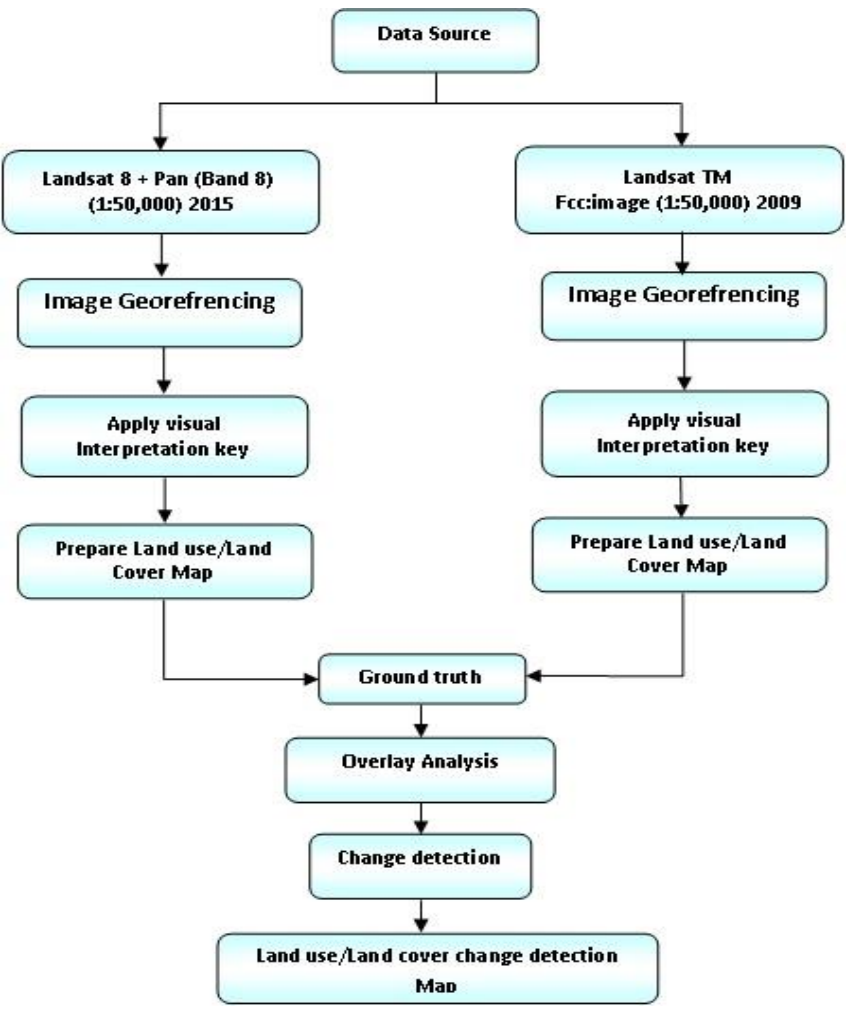

Fig.2. Flow chart showing the methodology of landuse/ landcover change detection

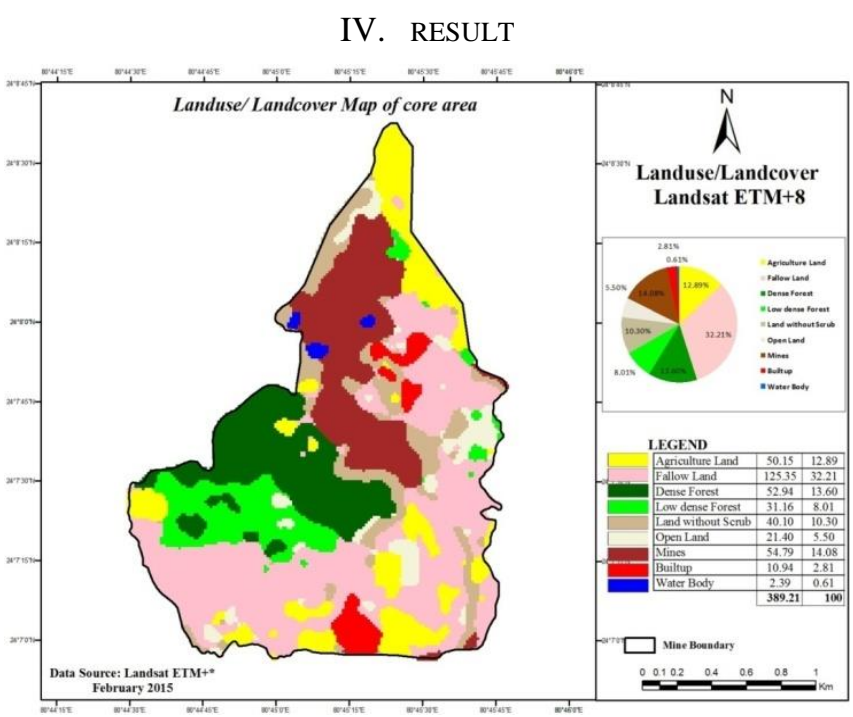

Fig.3. Landuse / landcover map of year 2015 (Core Area)

TABLE I: STATISTICS OF LAND USE/LAND COVER OF CORE ZONE (2015)

\begin{tabular}{lcc}
\hline \multicolumn{1}{c}{ Landuse Class } & Area in ha & Area in \% \\
\hline Agriculture land & 50.2 & 12.9 \\
Fallow Land & 125.3 & 32.2 \\
Dense Forest & 52.9 & 13.6 \\
Low Dense Forest & 31.2 & 8.0 \\
Land Without Scrub & 40.1 & 10.3 \\
Open Land & 21.4 & 5.5 \\
Mines & 54.8 & 14.1 \\
Builtup & 10.9 & 2.8 \\
Water Body & 2.4 & 0.6 \\
\hline \hline
\end{tabular}


The land use landcover map of core mine area is derived from landsat ETM+ merge data (2015) having $15 \mathrm{~m}$ resolution (Fig. $3 \&$ Table I). The major classes derived are fallow land $(32.2 \%)$, agriculture land $(12.9 \%)$, dense/closed forest $(13.6 \%)$, mines $(14.1 \%)$, land without scrub $(10.3 \%)$, low dense forest $(8 \%)$ and other classes delineated are built up $(2.8 \%)$, open / barren land $(5.5 \%)$ and water body $(0.6$ $\%)$.

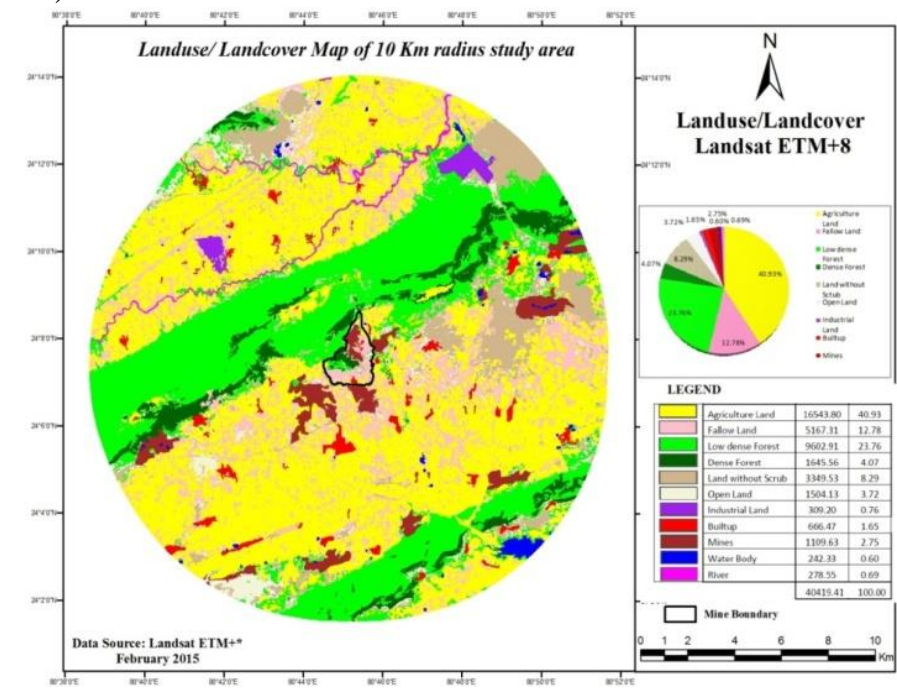

Fig.4. Landuse / landcover map of year 2015 (10 km radius study area)

TABLE II: STATISTICS OF LAND USE/LAND COVER OF 10 KM RADIUS ( 2015)

\begin{tabular}{lcc}
\hline \hline Landuse Class & Area in ha & Area in \% \\
\hline Agriculture Land & 16543.8 & 40.93 \\
Fallow Land & 5167.3 & 12.78 \\
Low dense Forest & 9602.9 & 23.76 \\
Dense Forest & 1645.6 & 4.07 \\
Land without Scrub & 3349.5 & 8.29 \\
Open Land & 1504.1 & 3.72 \\
River & 278.6 & 0.69 \\
Water Body & 242.3 & 0.6 \\
Built-up & 666.5 & 1.65 \\
Mines & 1109.6 & 2.75 \\
Industrial Land & 309.2 & 0.76 \\
\hline
\end{tabular}

The land use and land cover map of $10 \mathrm{~km}$ radius study area was prepared based on satellite data of 2015 (Fig. 4 \& Table II) revealed that out of the total geographical study area, agriculture land constitute $40.93 \%$ of the area (16543.8 ha.), and fallow land covering about $12.78 \%$ (5167.3 ha). The rest of the area is open/barren land $(3.72 \%)$, river $(0.69$ $\%)$, water body $(0.60 \%)$, built-up $(1.65 \%)$, mines and industrial land covers 2.27 and $0.76 \%$ respectively. Under the forest category, maximum area is covered by low dense forest constitute $23.76 \%$ (9602.9 ha), dense Forest (4.07\%), and land without scrub covers about $(8.29 \%)$ area.

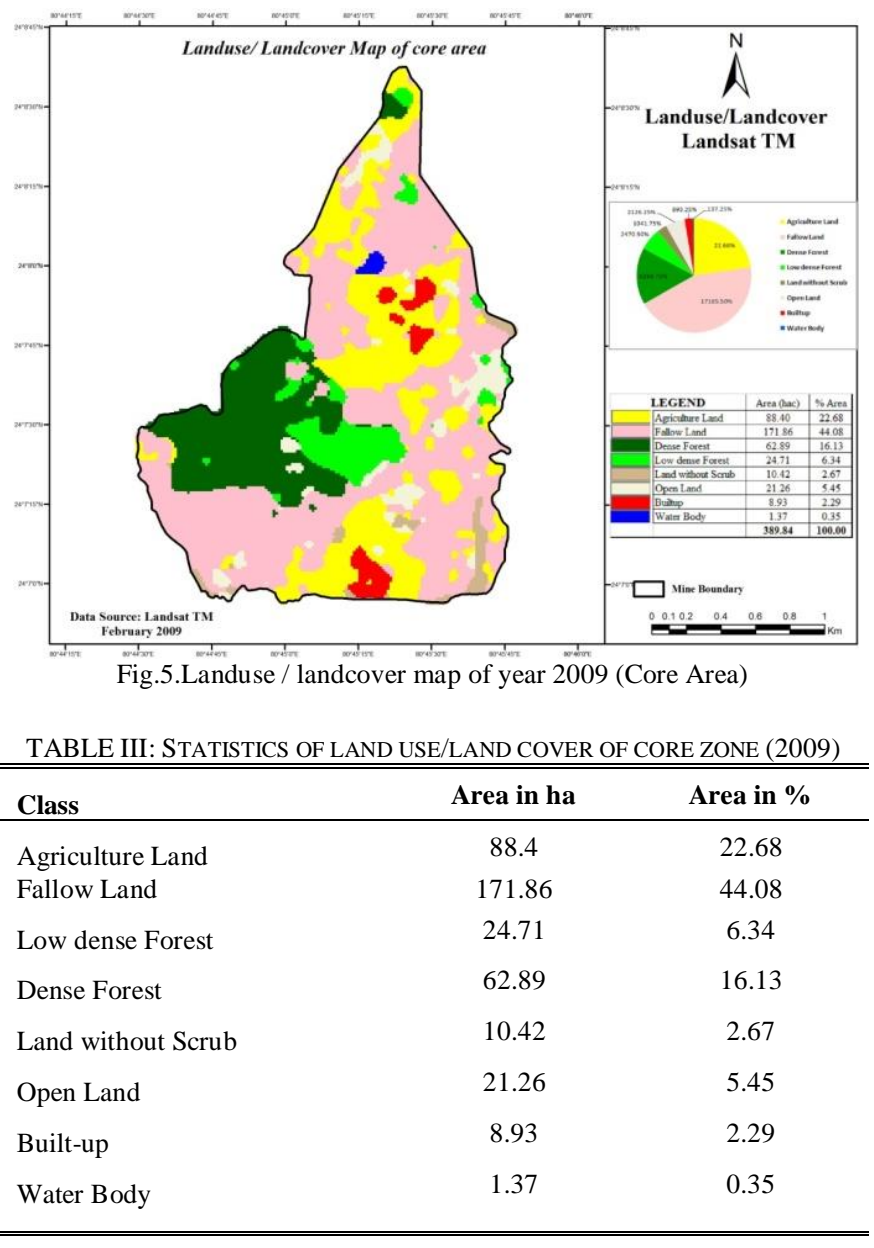

The land use landcover map of core mine area is derived from Landsat TM (2009) having 30 m resolution (Fig. 5 \& Table III). The major classes derived are fallow land (44.08 $\%$ ), agriculture land (22.68\%), dense/closed forest (16.13\% ), land without scrub (2.67\%), low dense forest (6.34\%) and other classes delineated are built up $(2.29 \%)$, open/ barren land $(5.45 \%)$ and water body $(0.0 .35 \%)$.

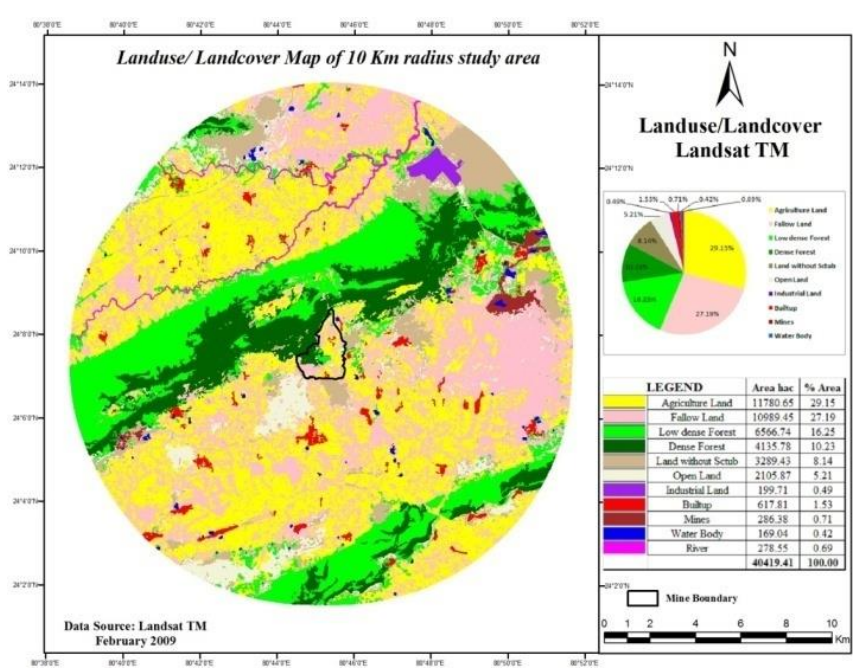

Fig.6.Landuse / landcover map of year 2009 (10 km radius study area) 
TABLE IV: STATISTICS OF LAND USE/LAND COVER OF 10 KM RADIUS (2009)

\begin{tabular}{lcc}
\hline \multicolumn{1}{c}{ Class } & Area in ha & Area in \% \\
\hline Agriculture Land & 11780.65 & 29.15 \\
Fallow Land & 10989.45 & 27.19 \\
Low dense Forest & 6566.74 & 16.25 \\
Dense Forest & 4135.78 & 10.23 \\
Land without Scrub & 3289.43 & 8.14 \\
Open Land & 2105.87 & 5.21 \\
Industrial Land & 199.71 & 0.49 \\
Built-up & 617.81 & 1.53 \\
Mines & 286.38 & 0.71 \\
Water Body & 169.04 & 0.42 \\
River & 278.55 & 0.69 \\
\hline \hline
\end{tabular}

The land use and land cover map of $10 \mathrm{~km}$ radius study area was prepared based on satellite data of 2009 (Fig. 6 \& Table IV) revealed that out of the total geographical study area, agriculture land constitute $29.15 \%$ of the area (11780.65 ha.), and fallow land covering about $27.19 \%$ (10989.45 ha). The rest of the area is open/barren land (5.21 $\%)$, river $(0.69 \%)$, water body $(0.42 \%)$, built-up $(1.53 \%)$, mines and industrial land covers 0.71 and $0.49 \%$ respectively. Under the forest category, maximum area is covered by low dense forest constitute $16.25 \%$ (6566.74 ha), dense forest $(10.23 \%)$, and land without scrub covers about $(8.14 \%)$ area.

A. Change occurs between the periods of 2009 to 2015: (10 km radius of study area)

TABLE V: STATISTICS OF LAND USE/LAND COVER CHANGE OF $10 \mathrm{KM}$ RADIUS AREA CORE AREA (2009 TO 2015)

\begin{tabular}{lcccc}
\multicolumn{5}{c}{ Landuse } \\
Class & $\mathbf{2 0 0 9 - 0 9}$ & $\mathbf{2 0 1 4 - 1 5}$ & $\begin{array}{c}\text { Change in } \\
\text { ha }\end{array}$ & $\begin{array}{c}\text { Change } \\
\text { in \% }\end{array}$ \\
\hline Agriculture & 11780.65 & 16543.8 & 4763.15 & 40.43 \\
Fallow & 10989.45 & 5167.3 & -5822.15 & -52.98 \\
Low dense & 6566.74 & 9602.9 & 3036.16 & 46.24 \\
Forest & 4135.78 & 1645.6 & -2490.18 & -60.21 \\
Dense Forest & 3289.43 & 3349.5 & 60.07 & 1.83 \\
Land without & 2105.87 & 1504.1 & -601.77 & -28.58 \\
Scrub & 278.55 & 278.6 & 0.05 & 0.02 \\
Open Land & 169.04 & 242.3 & 73.26 & 43.34 \\
River & 617.81 & 666.5 & 48.69 & 7.88 \\
Water Body & 286.38 & 1109.6 & 823.22 & 287.46 \\
Builtup & 199.71 & 309.2 & 109.49 & 54.82 \\
Mines & & & & \\
Industrial Land & & &
\end{tabular}

Fig.7.Statistics of land use/land cover change of $10 \mathrm{~km}$ radius study area (year 2009 \& 2015)

Out of the total geographical area of $40419.41 \mathrm{~km} 2$, agriculture constitutes $16543.80 \mathrm{~km} 2$ in 2014-15, which was $11780.65 \mathrm{~km} 2$ in 2009-10.Major cause of this unprecedented increase in area under agricultural use was transformation of fallow into agriculture. Landuse map clearly shows that about $50-60 \%$ of fallow land converted into agricultural land. The main reason of this land transformation is massive growth of population. It has been also observed that about 40 $\%$ of dense forest area is converted into low dense forest. The increase in mining area is about $287 \%$, in 2009-10 the mining area constitute 286.38 where as in 2014-15 it reaches $1109.60 \mathrm{~km} 2$.

\section{B. Change occurs between the periods of 2009 to 2015: (core study area)}

TABLE VI: STATISTICS OF LAND USE/LAND COVER CHANGE OF CORE AREA (2009 TO 2015)

\begin{tabular}{lcccc}
\hline \hline Landuse Class & $2009-09$ & $2014-15$ & $\begin{array}{c}\text { Change } \\
\text { in ha }\end{array}$ & $\begin{array}{c}\text { Change in } \\
\%\end{array}$ \\
\hline Agriculture Land & 88.4 & 50.15 & -38.25 & $-43.27 \%$ \\
Fallow Land & 171.86 & 125.35 & -46.51 & $-27.06 \%$ \\
Low dense Forest & 24.71 & 31.16 & 6.45 & $26.10 \%$ \\
Dense Forest & 62.89 & 52.94 & -9.95 & $-15.82 \%$ \\
Land without & 10.42 & 40.1 & 29.68 & $284.84 \%$ \\
Scrub & 21.26 & 21.4 & 0.14 & $0.66 \%$ \\
Open Land & 8.93 & 10.94 & 2.01 & $22.51 \%$ \\
Built-up & 1.37 & 2.39 & 1.02 & $74.45 \%$ \\
Water Body & 0 & 54.79 & 54.79 & $100 \%$ \\
Mining Area & & & & \\
\hline \hline
\end{tabular}

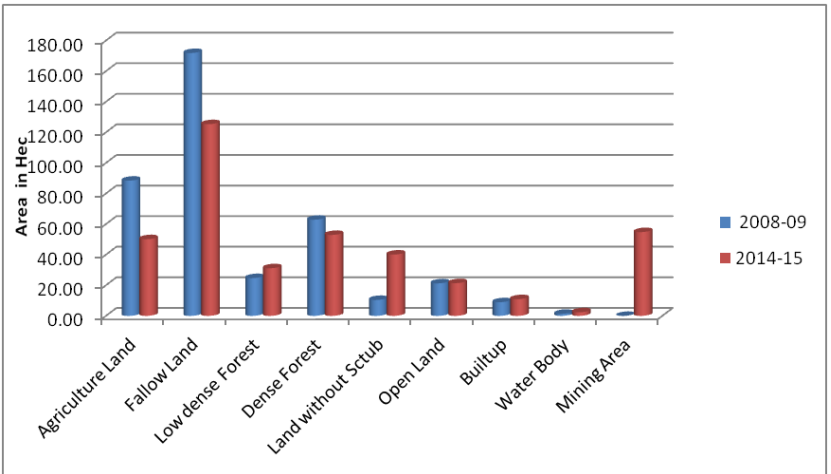

Fig. 8: Statistics of land use/land cover of core area (year $2009 \& 2015$ )

Out of the total geographical area of 389.84 ha, agriculture constitutes 50.15 ha in 2014-15, which was 88.80 ha in 200910 whereas fallow land constitutes 125.35 ha in 2014-15, which was 125.35 ha in 2009-10. Major cause of this 
unprecedented decrease in area under agricultural and fallow was transform into mining and land with or without scrub. Landuse map clearly shows that about $40-45 \%$ of fallow and agriculture land converted into mining and land with or without scrub. The main reason of this land transformation is to rapid growth of mining area.

\section{CONCLUSION}

The temporal change in land use /land cover was detected through preparation of land use/ land cover maps pertaining to $2009-10$ and $2014-15$ using multidate satellite data .The prepared maps were overlaid using GIS to obtain change detection statistics to know the changes occurred in different land use classes during 2009-2015. The following conclusions are derived from this study:

1) Remotely sensed data, especially satellite data can be effectively used in mapping as well as monitoring of temporal changes in land use/land cover of an area.

2) A considerable change in different land use/land cover categories was observed during 2009 to 2015 especially cropland, fallow land and mining area. Changes in forest sub-classes were also noticed in $10 \mathrm{~km}$ of radius study area where as in core area agriculture and fallow land converted into mining area.

3) The overall increase in mining area was $287.46 \%$ during 2009 to 2015 were noticed in $10 \mathrm{~km}$ of radius study area where as in core area totally new mining sites were formed.

4) Croplands also registered an overall increase of $40.43 \%$ in area during 2009-2015. The increase in area was as a result of transformation of fallow land into cropland in $10 \mathrm{~km}$ of radius study area.

5) In case of forest, the land transformation in dense, open and scrub was also observed for the period 20092015. During this period dense forest converted into low dense forest.

\section{ACKNOWLEDGMENT}

I acknowledge my greatest appreciation to my supervisor and guide Dr. Shashikant Tripathi, Associate Professor, Department of Energy \& Environment, Mahatma Gandhi Chitrakoot Gramodaya Vishwavidyalaya, Chitrakoot, Satna (M.P) for his untiring guidance valuable suggestions, intellectual criticisms, unfailing help and moral support throughout my work. I am thankful for his uninhibited guidance and encouragement and constant monitoring of the progress of my work to give successful completion of the research and his untiring help in the preparation and completion of this manuscript.

\section{REFERENCES}

[1] Allum, J.A. and Dreisinger, B.R. (1986). "Remote sensing of vegetation change near Inco's Sudbury mining complexes". Int. J. Remote Sensing. 8:399-416.

[2] Balak, R. and Kolarkar, A.S. (1993). "Remote Sensing application in monitoring land use changes in arid Rajasthan". Int. J. Remote sensing, vol no. 14 (17), page no. 3191-3200.

[3] Bansal, A. Karwariya S. and Goyal, S. (2012). "Change Detection in Land use / Land cover in Sewan Watershed Using Remote Sensing and GIS Technique". Int. Journal of Advances in Remote Sensing and GIS, Vol. 1, No. 2, 2012.
[4] Coppin, P.R. and Bauer, M.E. (1996)."Digital change detection in forest ecosystems with remote sensing imagery". Remote Sensing Reviews 13 (3-4), 207-234.

[5] CSE. (2009). Mining: "A Guide to India's Wealth, Its Resource Curse". [Online] Available at: http://www.cseindia.org (Accessed on 20.01.2012).

[6] Deer, J. P. (1995). "Digital change detection techniques", Civilian and Military Applications, Information Technology Division, Defence Science and Technology Organization, Australia (http://www.dtic.mil/cgibin/GetTRDoc?AD=ADA300761).

[7] Gautam, N.C. and Narayan, L.R.A. (1983). "Landsat MSS data for land use/land cover inventory and mapping - a case study of Andhra Pradesh", J. Indian Soc. Remote Sensing, 11(3), pp 15-28.

[8] Chilar, J. (2000). "Land cover mapping of large areas from satellites: status and research priorities". International Journal of Remote Sensing, 21(67), pp 1093-1114.

[9] Karwariya, S. and Tripathi, S. (2012). "Landuse/Landcover Mapping of Achanakmar Amarkantak Biosphere Reserve, India Using Unsupervised Classification Technique". International Journal of Computational Engineering Research (ijceronline.com) Vol. 2 Issue. 5.

[10] Karwariya, S. and Goyal, S. (2011). "Land use and Land Cover mapping using digital classification technique in Tikamgarh district, Madhya Pradesh, India using Remote Sensing". International Journal of geomatics and geosciences Volume 2, No 2, 2011.

[11] Mishra, A., Karwariya, S. and Goyal, S. (2012) "Land use / Land cover Mapping of Chhatarpur District, Madhya Pradesh, India Using Unsupervised Classification Technique" IOSR Journal of Engineering, Volume 2, Issue 10, PP 51-56.

[12] Lillesand, T., Kiefer, R. and Chipman, J., (2004). "Remote Sensing and Image Interpretation", John Wiley \& Sons, Singapore, 2004 5 thedition.

[13] Meyer, W.B., (1995). "Past and Present Land-use and Land-cover in the U.S.A". Consequences, Ministry of Finance and Planning, Draft National Strategic Plan 2006, National Physical Development Plan Trinidad vol.no. 28 page no. 45 .

[14] Morisette, J.T., Khorram, S., (2000). "Accuracy assessment curves for satellite-based change detection”. Photogrammetric Engineering and Remote Sensing 66 (7), 875-880.

[15] S.Sudhakar. (1999). "Techniques of Classification for Land use/Land cover with special reference for Forest type mapping in Jaldapara Wild life Sanctuary". Journal of the Indian society of Remote Sensing, Vol 27.No.4, 1999.

[16] Tahir M., M. R. Javed, A. Tanveer, M. A. Nadeem and A. Wasaya, S.A.H. Bukhari and J. U. Rehman (2009). "Effect of different herbicides on weeds, growth and yield of spring planted maize" (Zea mays L.). Pak. J. Life Soc. Sci. 7(2): 168-174.

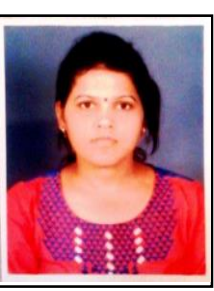

Miss.Awantika Tiwari is a master's student of Remote sensing \& GIS at Mahatma Gandhi Chitrakoot Gramodaya Vishwavidyalaya, Satna Madhya Pradesh (India). She was compleated her graduation in Information technology from Uttar Pradesh Technical University, Lucknow ,India

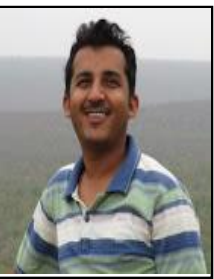

Dr.Sateesh Karwariya is a Resaerch Associate in Indian Institute of Soil Science, Bhopal India. $\mathrm{He}$ obtain master of remote sensing \& GIS from Jiwaji University Gwalior (India) and $\mathrm{Ph}$. D. in Remote sensing \& GIS at Mahatma Gandhi Chitrakoot Gramodaya Vishwavidyalaya, Satna Madhya Pradesh (India).

He has over 7 years of research as well as professional experience in the field of remote sensing $\&$ GIS in various fileds. He has published numerous refereed articles in professional journals.

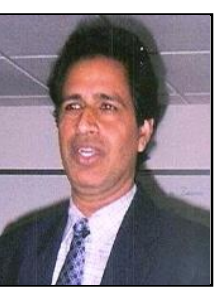

Prof. Shashikant Tripathi is Associate Professor and Head, Remote Sensimg \& GIS division in Mahatma Gandhi Chitrakoot Gramodaya Vishwavidyalaya, Satna Madhya Pradesh (India). He has over 25 years of Teaching as well as research experience in the field of Remote Sensing, GIS, Environment, Geology and Geography. He has published numerous refereed articles in professional journals. 